\title{
Prediction of Perineal Tear During Childbirth by the Assessment of Striae Gravidarum Score
}

\author{
Mahbuba Akhter Banu 1, S F Nargis ${ }^{2}$, Mohammad Mizanoor Rahman *3, Md. Mohim Ibn Sina ${ }^{4}$, \\ Murshida Pervin ${ }^{5}$, Mamata Manjari ${ }^{6}$
}

\section{Abstract}

Introduction: Perineal tear (PT) is the most frequently occurring injury during vaginal birth. Striae gravidarum (SG) is a reflecting marker of connective tissue elasticity. This study aimed to assess SG score and to predict the likelihood of PT during childbirth. Materials \& Methods: This was a cross-sectional study done at Sir Salimullah Medical College \& Mitford Hospital. Initially, all pregnant women admitted for vaginal delivery were enrolled but who subsequently needed lower segment caesarean section were excluded. Finally, 189 patients who gave vaginal birth were included. SG score was assessed using the Atwal numerical scoring system. The association was examined between PT as the outcome measure, defined by tears or lacerations and the total striae score (TSS) obtained at abdomen, hips, buttocks and breasts. Results: More than half of study patients developed PT. Majority belonged to moderate striae group. Significant correlation was found between PT and TSS. Moderate and severe striae had significantly increased prevalence of PT as compared to mild striae (43.4\% vs. 11.6\%). Patients who were given episiotomy in moderate and severe striae group had less PT. Weight gain during pregnancy and TSS were significantly associated with a higher incidence of PT. Conclusion: A woman's SG score in general is a useful clinical predictor of the risk for PT during childbirth. Selective episiotomy in patients with moderate and severe striae can reduce the incidence of PT. SG score can be used as a simple and noninvasive tool by all categories of health personnel to better define women at risk for PT.

Keywords: Perineal tear, Striae gravidarum score.

Number of Tables: 05; Number of References: 13; Number of Correspondences: 06

\section{Dr. Mahbuba Akhter Banu}

Associate Professor

Department of Obs. \& Gynae

Sir Salimullah Medical College and

Mitford Hospital, Dhaka.

2. Dr. S F Nargis

Professor

Department of Obs. \& Gynae

Sir Salimullah Medical College and

Mitford Hospital, Dhaka.

*3. Corresponding Author:

Dr. Mohammad Mizanoor Rahman

Assistant Professor

Department of Anesthesiology

Institute of Child and Mother Health (ICMH), Dhaka.

E-mail: drmijan74@gmail.com

Mobile: +8801813590300

4. Dr. Md. Mohim Ibn Sina

FCPS Part-II Course Student

Department of Obs. \& Gynae

Bangabandhu Sheikh Mujib Medical University, Shahbag, Dhaka.

5. Dr. Murshida Pervin

Assistant Professor

Department of Obs. \& Gynae

Sir Salimullah Medical College and

Mitford Hospital, Dhaka.

6. Dr. Mamata Manjari

Junior Consultant

Department of Obs. \& Gynae

250 Bedded District Hospital, Manikganj.

\section{Introduction}

Perineal trauma is associated with significant short- and long-term morbidity for puerperal women. Acute postpartum perineal pain is very common suffering of women who give birth vaginally and its severity is linked exclusively to that of the perineal injury ${ }^{1}$. Perineal injury may be caused either by surgically-planned episiotomy, or spontaneously occurring injury during labour process. Perineal injuries may also trigger some complications such as urinary and fecal incontinence, dyspareunia and pelvic floor disorders ${ }^{2,3}$.

Perineal tear (PT); the most common and frequently occurring form of perineal injury, may be classified as first degree when injury involving perineal skin and mucosa, second degree when extending to perineal muscles and third degree when reaching anal sphincter muscle. These injuries depend on several factors related to mother, fetus and delivery conditions ${ }^{4}$.

Striae distensae (SD), or 'stretch marks', though found in a variety of physiological and pathological conditions, are widely associated with pregnancy and are referred to as striae gravidarum $(\mathrm{SG})^{5}$. SG is a common disfiguring condition of pregnancy and an indicator of poor skin elasticity ${ }^{6}$. There are two forms of SD; striae rubra and striae albae. The acute stage (striae rubra) is characterized by the initial erythematous, red and stretched flat (in some cases appear slightly raised) lesions which are aligned perpendicular to the direction of skin tension, whilst the chronic stage (striae alba) is classified when SD have faded and appear atrophic, wrinkled, and hypopigmented6. Striae have been noted to occur in more than $70 \%$ of pregnant women and are commonly found on the abdomen and breasts. They tend to 
develop in the third trimester and fade during postpartum leaving behind permanent silvery scars ${ }^{5,7}$. SG is caused by hormonally-induced changes in the alignment of structural connecti tissue and reduced elastin and fibrillin in the underlying dermis. The type and amount of collagen in connective tissue are considered to determine the individual's elastic index ${ }^{8,9}$.

Several epidemiological studies have demonstrated that perineal trauma largely correlates with maternal, fetal and delivery factors ${ }^{1,7,8}$. Classifications for these complications have been devised and named by urogynecologists and obstetricians as Obstetric and Anal Sphincter Injuries (OASIS) ${ }^{9,10}$. A woman's connective tissue elasticity contributes as a factor in maintaining an intact perineum during child birth whereas SG can be considered as a reflecting marker for connective tissue elasticity ${ }^{4}$. Assessment of SG can be performed by midwives and nurses with no need for special equipment or training and via noninvasive, simple observation. Several studies concluded that SG assessment appears to predict the occurrence of PT and recommended training the health personnel to calculate the total striae score (TSS) which can help them to decide if episiotomy is to be given or $\operatorname{not}^{8-10}$.

Vaginal birth is common in our low income setting country. PT commonly follows vaginal delivery along with significant short- and long-term morbidities ${ }^{1}$. Assessing SG score may be considered as a favorable process to predict the occurrence of perineal injury ${ }^{9,10}$. Episiotomy definitely seems to be preventive for PT but giving episiotomy for the same is still debatable as episiotomy itself is associated with morbidity ${ }^{11}$. Moreover, supportive data regarding this issue is very scarce in our country. So, this study was aimed to determine whether assessment of SG score could predict the occurrence of PT during vaginal birth or not, and if episiotomy will prevent PT in women with high score.

\section{Materials and Methods}

This cross-sectional study was conducted in the Department of Obstetrics and Gynaecology of Sir Salimullah Medical College \& Mitford Hospital, Dhaka from January 2017 to July 2017. Initially, all pregnant women admitted for vaginal delivery were enrolled but subsequently who needed lower segment caesarean section was excluded. Finally, 189 patients were included who delivered vaginally. Severity scoring of SG was observed using the numerical scoring system of Atwa $1^{10}$. This scale provides a rank based on observation of four areas in which SG is most commonly observed (abdomen, hips, buttocks and breasts). The scale comprises the following criteria: (a) the number of $\mathrm{SG}$ at each body site $(0=$ no striae, $1=1-4$ striae, $2=$ 5-10 striae, $3=$ more than 10 striae) and (b) the color of the SG which ranges from pale to purple $(0=$ no redness, $1=$ pink, 2 = dark red, 3 = purple). Silvery white striae were considered old striae developed prior to pregnancy and were therefore not included in this study. The final score, considering number and color for each body site, ranged from 0 to 6 . Accordingly, the TSS for all four-body sites ranged from 0 to 24 . Women who scored up to 12 were considered having mild striae, $13-18$ as moderate striae and more than 18 as severe striae. After vaginal delivery, each study patient was examined for PT. All medical, obstetric and demographic data were recorded in a pre-structured, interview and observation-based case record form. Data were summarized in mean $\pm \mathrm{SD}$, frequency \& percentage and presented in tables using Statistical Package for Social Science (SPSS) version 23. Variables statistically significant in predicting PT namely SG score and episiotomy was analyzed.

\section{Results}

In this study, most of the respondents 180 (95.3\%) were housewife and majority $170(89.9 \%)$ had only primary education (Table-I). More than half 104 (55.1\%) of the study population developed PT (Table-II). Majority $(53.4 \%)$ belonged to moderate striae group whereas only $8.9 \%$ had severe striae (Table II). Statistically significant $(p<0.001)$ correlation was observed between PT and SG score. Patients with moderate and severe striae had significantly increased prevalence of PT as compared to mild striae (43.4\% vs. $11.6 \%)$ (Table III). Patients who were given episiotomy in moderate and severe striae group had significantly less PT $(\mathrm{p}<0.01)$ (Table IV). Weight gain during pregnancy and TSS were significantly associated ( $p$ $<0.05$ ) with a higher incidence of PT but without significant association of birth weight of newborns (Table V).

Table-I: Descriptive statistics of study pregnant mothers.

\begin{tabular}{lc}
\hline Variables & Values \\
\hline Age (years ) & $25.4 \pm 4.9$ \\
Para & $1.45 \pm 0.91$ \\
Gravida & $1.69 \pm 1.00$ \\
Educational status & \\
Primary & $170(89.9)$ \\
Secondary and above & $19(10.1)$ \\
Occupational status & \\
Housewife & $180(95.3)$ \\
Teacher & $5(2.6)$ \\
Services & $4(2.1)$ \\
Weight gain during pregnancy $(\mathrm{kg})$ & $8.30 \pm 1.94$ \\
Birth weight of newborn $(\mathrm{kg})$ & $2.73 \pm 0.16$ \\
\hline
\end{tabular}

*Values expressed as Mean $\pm S D$ or numbers (n) and percentages (\%) in parentheses, as appropriate; SD, standard deviation. 
Table-II: Distribution of striae gravidarum score and perineal tear.

\begin{tabular}{lcc}
\hline Variables & Frequency & Percent (\%) \\
\hline Striae gravidarum score & & \\
Mild striae & 71 & 37.7 \\
Moderate striae & 101 & 53.4 \\
Severe striae & 17 & 8.9 \\
Perineal tear & & \\
Yes & 104 & 55.1 \\
No & 85 & 44.9 \\
\hline
\end{tabular}

Table-III: Striae gravidarum score versus perineal tear.

\begin{tabular}{lccc}
\hline $\begin{array}{l}\text { Striae } \\
\text { gravidarum } \\
\text { score }\end{array}$ & $\begin{array}{c}\text { No perineal } \\
\text { tear } \\
(\mathbf{n}=85)\end{array}$ & $\begin{array}{c}\text { Perineal } \\
\text { tear } \\
(\mathbf{n}=104)\end{array}$ & p value \\
\hline Mild striae & $49(25.9)$ & $22(11.6)$ & \\
Moderate striae & $33(17.4)$ & $68(36.0)$ & $<0.001$ \\
Severe striae & $3(1.6)$ & $14(7.4)$ & \\
\hline
\end{tabular}

*Values expressed as number ( $n$ ) and percentages (\%) in parentheses; $p$ value was obtained by Chi-square test; 0.05 was considered as level of significance.

Table-IV: Episiotomy in different categories of striae gravidarum score.

\begin{tabular}{|c|c|c|c|c|c|c|}
\hline $\begin{array}{l}\text { Striae } \\
\text { gravidarum } \\
\text { score }\end{array}$ & \multicolumn{2}{|c|}{ Episiotomy } & \multicolumn{2}{|c|}{$\begin{array}{l}\text { No } \\
\text { perineal } \\
\text { tear }\end{array}$} & $\begin{array}{c}\text { Perineal } \\
\text { tear }\end{array}$ & $\begin{array}{c}\mathrm{p} \\
\text { value }\end{array}$ \\
\hline \multirow{2}{*}{ Mild striae } & \multicolumn{2}{|l|}{ Given } & \multicolumn{2}{|c|}{$15(7.9)$} & $7(3.7)$ & \multirow{2}{*}{0.23} \\
\hline & \multicolumn{2}{|c|}{ Not given } & \multicolumn{2}{|c|}{$34(17.9)$} & $15(7.9)$ & \\
\hline \multirow{2}{*}{$\begin{array}{l}\text { Moderate } \\
\text { striae }\end{array}$} & \multicolumn{2}{|l|}{ Given } & \multicolumn{2}{|c|}{$22(11.7)$} & $16(8.5)$ & \\
\hline & \multicolumn{2}{|c|}{ Not given } & \multicolumn{2}{|c|}{$11(5.8)$} & $52(27.5)$ & \\
\hline \multirow{2}{*}{ Severe striae } & \multirow{2}{*}{\multicolumn{2}{|c|}{$\begin{array}{l}\text { Given } \\
\text { Not given }\end{array}$}} & \multirow{2}{*}{\multicolumn{2}{|c|}{$\begin{array}{l}2(1.1) \\
1(0.5)\end{array}$}} & $1(0.5)$ & \multirow{2}{*}{$<0.01$} \\
\hline & & & & & $13(6.9)$ & \\
\hline \multicolumn{7}{|c|}{$\begin{array}{l}\text { *Values expressed as number }(\mathrm{n}) \text { and percentages }(\%) \text { in } \\
\text { parentheses; } p \text { value was obtained by Chi-square test; } \\
0.05 \text { was considered as level of significance }\end{array}$} \\
\hline \multicolumn{7}{|c|}{$\begin{array}{l}\text { Table-V: Logistic regression for the prediction of risk for } \\
\text { perineal tear by weight gain during pregnancy }(\mathrm{kg}) \text {, total } \\
\text { striae score (TSS) and birth weight of newborns }(\mathrm{kg}) \text {. }\end{array}$} \\
\hline \multirow{2}{*}{\multicolumn{2}{|c|}{ Variables }} & \multirow{2}{*}{\multicolumn{2}{|c|}{$\begin{array}{c}\text { Odds } \\
\text { ratio }\end{array}$}} & $\mathrm{p}$ & \multirow{2}{*}{\multicolumn{2}{|c|}{$\begin{array}{l}\text { OR Lower OR Upper } \\
95 \% \mathrm{CI} \quad 95 \% \mathrm{CI}\end{array}$}} \\
\hline & & & & & & \\
\hline \multicolumn{2}{|l|}{$\overline{\mathrm{TSS}}$} & & & 0.020 & 1.051 & 1.141 \\
\hline \multicolumn{2}{|c|}{ Weight gain during pregnancy } & & & 0.034 & 1.000 & 1.002 \\
\hline \multicolumn{2}{|c|}{ Birth weight of newborns } & & & 0.312 & 1.002 & 1.003 \\
\hline
\end{tabular}

\section{Discussion}

The aim of this study was to determine whether SG score can be used as a predictor of PT at the time of vaginal delivery. Therefore, TSS can be used as an additional valuable predictor of the risk for PT.
In this observational study, $170(89.9 \%)$ study patients completed their primary education but only $19(10.1 \%)$ completed secondary education. Halperin et al. showed most of the study patients at least completed high school which is not consistent with this resul ${ }^{12}$. More than half of the study patients $(55.1 \%)$ developed PT and this finding was almost similar to finding by Alves et al ${ }^{9}$. It was observed that there was statistically significant correlation between PT and severity of SG score (Table III). Mild striae score showed significantly less prevalence of PT (11.6\% vs. 25.9\%). On contrary, PT was significantly higher in moderate \& severe striae group $(36.0 \%$ and $7.4 \%$ ). Thus SG score was significantly higher in PT cases than no PT cases. Significantly higher striae score was also found by Halperin et al. ${ }^{12}$ in women with PT compared with women without PT. Osman et al. ${ }^{8}$ showed severity of SG was the predictors of PT which is consistent with this study result. Patients of moderate and severe striae group who were given episiotomy had significantly less PT (Table IV). This suggests that patients who had an episiotomy were less likely to develop perineal tear in most cases. Therefore, this study found that episiotomy has some protective effect against PT. Kapadia et al. ${ }^{13}$ also showed similar result. To investigate the role of SG score in predicting the risk for PT, logistic regression analysis was done considering TSS, weight gain during pregnancy and birth weight of newborns among the 126 women in whom episiotomy was not performed. Weight gain during pregnancy and TSS were significantly associated with a higher incidence of PT but without significant association of birth weight of newborns. Halperin et al. ${ }^{12}$ showed similar result.

\section{Conclusion}

This study concludes that a significant prediction of PT can be done during childbirth using SG score and selective episiotomy can reduce the incidence of PT in patients with moderate and severe striae. The findings suggest that SG assessment may be used in the clinical setting by clinicians, midwives as well as nurses as a straightforward, simple and noninvasive tool to better define women at risk for PT.

\section{Conflict of Interests: None.}

\section{Acknowledgement}

The authors would like to thank all participating patients for taking part in this study. We are greatly indebted to the institutional obstetric team for their endless support. The authors would like to thank specially our Head of Department for her continuous guidance.

\section{References}

1. Kenyon S., Ford F. How can we improve women's post birth perineal health? MIDIRS Midwifery Digest. 2004; 14(1): 7-12.

2. Almeida SF, Riesco ML. Randomized controlled clinical trial on two perineal trauma suture techniques in 
normal delivery. Rev Lat Am Enfermagem. 2008; 16(2): 272-9.

https://doi.org/10.1590/S0104-11692008000200016

3. Carroli G, Mignini L. Episiotomy for vaginal birth. Cochrane Database Syst Rev. 2009; (1): CD000081.

https://doi.org/10.1002/14651858.CD000081.pub2

4. Costa AV, Sales RM, Moura FM, Costa RS, Moura LJ. Vivencia das mulheres sobre a episiotomia. Rev Enferm UFPI. 2012; 1(1): 50-5.

5. Murray J.C. Pregnancy and the skin. Dermatologic clinics. 1990; 8(2): 327-334.

https://doi.org/10.1016/S0733-8635(18)30504-7

6. Weedon D. Disorders of collagen. In: Weedon D, editors.Û́Skin Pathology. 2nd ed. New York: Churchill Livingstone; 2002: 358-9.

7. Muzaffar F, Hussain I, Haroon T.S. Physiologic skin changes during pregnancy: a study of 140 cases. International journal of dermatology. 1998; 37(6): 429-431.

https://doi.org/10.1046/j.1365-4362.1998.00281.x

PMid:9646127

8. Osman H, Rubeiz N, Tamim H, Nassar A.H. Risk factors for the development of striae gravidarum. American journal of obstetrics and gynecology. 2007; 196(1): 62-e1. https://doi.org/10.1016/j.ajog.2006.08.044

PMid:17240237 PMCid:PMC1913631
9. Alves G.F, Nogueira L.S.C., Varella T.C.N. Dermatology and pregnancy. Anais brasileiros de dermatologia. 2005; 80(2): 179-186.

https://doi.org/10.1590/S0365-05962005000200009

10. Atwal G.S.S., Manku L.K., Griffiths C.E.M., Polson D.W. Striae gravidarum in primiparae. British Journal of Dermatology. 2006; 155(5): 965-969.

https://doi.org/10.1111/j.1365-2133.2006.07427.x

PMid: 17034526

11. Royal College of Obstetricians and Gynecologists. Methods and Materials Used in Perineal Repair. Guideline No. 23. London; 2004.

12. Halperin O, Raz I, Bengal L., Or-Chen K, Granot M. Prediction of perineal trauma during childbirth by assessment of striae gravidarum score. Journal of Obstetric, Gynecologic, \& Neonatal Nursing. 2014; 39(3): 292-297. https://doi.org/10.1111/j.1552-6909.2010.01137.x

PMid:20576071

13. Kapadia S, Kapoor S, Parmar K, Patadia K, Vyas M. Prediction of perineal tear during childbirth by assessment of striae gravidarum score. International Journal of Reproduction, Contraception, Obstetrics and Gynecology. 2016; 3(1): 208-212.

https://doi.org/10.5455/2320-1770.ijrcog20140342 